ks. Janusz Mariański

Katolicki Uniwersytet Lubelski Jana Pawła II

DOI: 10.15290/std.2016.02.09

\title{
SAKRAMENT MAŁŻEŃSTWA W ŚWIADOMOŚCI KATOLIKÓW POLSKICH W KONTEKŚCIE PRZEMIAN RODZINY
}

\section{THE SACRAMENT OF MARRIAGE IN THE CONSCIOUSNESS OF POLISH CATHOLICS IN THE CONTEXT OF THE TRANSFORMATION OF THE FAMILY}

The paper presents the view of Polish Catholics on Sacrament of Marriage by focusing mostly on its social and cultural rather than theological aspects. We discuss believers understanding of sacramental marriage at the background of changes that took place in Polish society at the beginning of the $21^{\text {th }}$ century and affected marriage and family. Our discussion is developed in three stages: the value of church wedding, the sacramental nature of marriage and the family, and admitting too Holy Communion people living in non-sacramental union.

As expected, the understanding of the sacramental character of marriage situates at a low level. Sociological studies on this subject are few, and they indicate that only minority of the young people give the correct answer to the question of sacramental character of Catholic marriage. Still, most respondents choose the answer that the sacrament of marriage is indissoluble. Others point to certain aspects of the sacramental marriage, which are like a side effect of the sacramental character of marriage. Finally, from $10 \%$ to $15 \%$ of respondents admit state that they do not know what the Sacrament of Marriage is.

There is a significant gap between the moral and religious teaching of the Catholic Church regarding people living in non-sacramental union, and attitudes of Catholics to this issue. Sociological studies show quite divergent views 
regarding the question whether a person not living in a sacramental union should be admitted to Holy Communion, and ranged from $44.0 \%$ to $81.7 \%$. According to Centre for Public Opinion Research (CBOS) survey this indicator covered nearly four fifths of adult Poles on a national scale.

From a sociological point of view, there are three possible solutions to the existing conflicts and tensions: First, change of the moral teaching of the Church, second, reorientation of moral attitudes of believers, and third, drifting away from the Church, and acceleration of secularization of society.

Key words: sacrament of marriage, the collective consciousness, youth, social and cultural transformation of the family.

Joseph kard. Ratzinger w jednym ze swoich wywiadów zauważyl, że „w kulturze świata uprzemysłowionego zerwane zostały przede wszystkim związki między sferą seksualną a małżeństwem. Oderwany od małżeństwa seks, nieuporządkowany i pozbawiony odniesienia, stał się na podobieństwo «pozostawionej miny» problemem i zarazem siłą wszechobecną. Zerwanie tego podstawowego związku prowadzi konsekwentnie do następnego pęknięcia: Skoro już dokonało się oddzielenie sfery seksualnej od małżeństwa, nastąpił również rozdział między seksem a prokreacją i tu także dokonało się odwrócenie porządku - zupełne oderwanie prokreacji od seksu. Stąd właśnie wzięły się owe straszliwe eksperymenty, których tak wiele w naszych czasach, eksperymenty technologiczne, inżynieria medyczna, które usiłują uniezależnić prokreację od sfery doznań seksualnych. Manipulacje biologiczne prowadzą prostą drogą do wyrzucenia człowieka poza granice właściwej mu natury (przez co zanegowano nawet jej koncepcję). Usiłuje się przekształcić człowieka manipulując nim, jak gdyby chodziło tu o jakąśs «rzecz», o nic więcej niż produkt zaplanowany według upodobania"1.

Socjologowie podkreślają, że moralność prorodzinna w społeczeństwach współczesnych staje się coraz bardziej autonomiczna, niezależna od religijności. Można mówić o swoistej dysharmonii między doktryną moralną Kościoła a rzeczywistymi postawami katolików w zakresie moralności małżeńskiej i rodzinnej. W warunkach istnienia alternatywnych uniwersów symbolicznych, przyjmowane przez jednostkę uniwersum moralne jest jednym z wielu. Może ono podlegać stopniowemu rozpadowi, kształtować się jako nieuporządkowana struktura złożona $z$ wielu niespójnych elementów wywodzących się z różnych źródeł, może wzmacniać się i zyskiwać nowe kształty kompatybilne z nowymi warunkami społeczno-kulturowymi lub kształtować się jako moralność prywatna. O ile dystansowanie się w sferze moralnej od nauki Kościoła katolickiego

Raport o stanie wiary. Z Ks. Kardynatem Josephem Ratzingerem rozmawia Vittorio Messori, Kraków - Warszawa-Struga 1986 s. 72. 
uznamy za specyficzny wskaźnik sekularyzacji, to z pewnością można mówić o procesach sekularyzacyjnych, także w Polsce, już od dłuższego czasu.

Kościół katolicki broni rodziny opartej na małżeństwie, w której panuje miłość i prawdziwa solidarność, przeciwstawiając się stawianiu na tej samej płaszczyźnie rodziny opartej na małżeństwie oraz innego rodzaju związkach emocjonalnych (tzw. wolne związki, małżeństwa „na etapy”, ad experimentum, konkubinat nienastawiony na przyjęcie formy więzi instytucjonalnej i inne). Sprzeciwia się on różnym eksperymentom nad rodziną. Zwraca uwagę na to, że środki społecznego przekazu, zwłaszcza telewizja i internet, lansują błędne koncepcje życia małżeńskiego i rodzinnego, a także sprzeczne z chrześcijaństwem systemy wartości. Tylko rodzina - powstała dzięki małżeństwu, podstawowemu związkowi między mężczyzną i kobietą - może stać się stabilnym i zrównoważonym środowiskiem rozwoju dziecka, zbudowanym na więziach uczuciowych i wzorach osobowościowych matki i ojca (przemówienie Jana Pawła II do nowego ambasadora Belgii w dniu 31 października 2002 roku) ${ }^{2}$.

Kościół katolicki bardzo silnie akcentuje sakramentalny charakter małżeństwa i wynikające $z$ niego konsekwencje dla życia małżeńskiego i rodzinnego. Chrystus przywrócił małżeństwu pierwotny porządek zamierzony przez Boga, daje łaskę do przeżywania małżeństwa w nowym sakramentalnym wymiarze, który jest znakiem Jego oblubieńczej miłości do Kościoła. W Kompendium Katechizmu Kościoła Katolickiego czytamy: „Sakrament małżeństwa rodzi między małżonkami węzeł wieczysty i wyłączny. Zgoda, przez którą małżonkowie oddają się sobie i przyjmują wzajemnie, zostaje przypieczętowana przez samego Boga. Dlatego zawarte i dopełnione małżeństwo osób ochrzczonych nie może być nigdy rozwiązane. Ponadto sakrament ten udziela małżonkom koniecznej łaski do osiągnięcia w życiu małżeńskim świętości oraz odpowiedzialnego przyjęcia dzieci i ich wychowania" (nr 346) ${ }^{3}$.

W naszych rozważaniach pomijamy aspekty teologiczne sakramentu małżeństwa i koncentrujemy się wyłącznie na kontekście społeczno-kulturowym odnoszącym się do świadomości religijno-moralnej ludzi wierzących. Zagadnienie świadomości sakramentalnego małżeństwa ukazujemy na tle przemian małżeństwa i rodziny w społeczeństwie polskim XXI wieku, w którym także dokonuje się antropologiczno-kulturowa zmiana wpływająca na wszystkie aspekty życia ludzkiego. Całość niniejszych rozważań zawiera się w trzech punktach: wartość ślubu kościelnego, sakramentalny charakter małżeństwa i rodziny, dopuszczenie do komunii eucharystycznej osób żyjących w związkach niesakramentalnych.

„L'Osservatore Romano”, 24(2003) nr 1 s. 41.

Kompendium Katechizmu Kościoła Katolickiego, Kielce 2005 s. 113. 


\section{Wartość ślubu kościelnego w świadomości Polaków}

Katechizm Kościoła Katolickiego podkreśla sakramentalny charakter małżeństwa katolickiego. To sami małżonkowie udzielają sobie nawzajem sakramentu małżeństwa, wypowiadając w asyście Kościoła swoją zgodę4. Dwa aspekty małżeństwa - wymiar naturalny i nadprzyrodzony - nie są od siebie niezależne, lecz spotykają się wzajemnie tak, jak prawda o Bogu i człowieku. Rzeczywistość ludzka splata się w przedziwny sposób z rzeczywistością Boską. Papież Paweł VI w encyklice Humanae vitae podkreślał, że dla ludzi ochrzczonych „małżeństwo nabiera godności sakramentalnego znaku, ponieważ wyraża związek Chrystusa z Kościołem" ${ }^{5}$. Małżeństwo sakramentalne jest związkiem nierozerwalnym, czyli związkiem mężczyzny i kobiety na całe życie. Nierozerwalność związku małżeńskiego jest stałym punktem kontrowersji między etyką katolicką i różnymi odmianami etyk laickich.

Według stanowiska Kościoła katolickiego małżeństwo jest pojmowane jako sakrament, czyli znak widzialny niewidzialnej łaski, udzielanej małżonkom do wypełniania podjętych zadań rodzicielskich. Związkowi małżńskiemu uświęconemu przez Boga przysługuje atrybut nierozerwalności. Według Katechizmu Kościoła Katolickiego: „Przymierze małżeńskie, przez które mężczyzna i kobieta tworzą ze sobą wspólnotę całego życia, skierowaną ze swej natury na dobro małżonków oraz do zrodzenia i wychowania potomstwa, zostało między ochrzczonymi podniesione przez Chrystusa Pana do godności sakramentu"6.

„Sakrament małżeństwa jest znakiem związku Chrystusa i Kościoła. Udziela on małżonkom łaski miłowania się wzajemnie tą miłością, jaką Chrystus umiłował Kościól. Łaska sakramentu udoskonala zatem ludzką miłość małżonków, umacnia ich nierozerwalną jedność i uświęca ich na drodze do życia wiecznego"7. Istotne przymioty małżeństwa: jedność i nierozerwalność, nabierają w małżeństwie chrześcijańskim szczególnej mocy z racji sakramentu ${ }^{8}$.

Papież Jan Paweł II wielokrotnie akcentował znaczenie religijnego wymiaru małżeństwa. W przemówieniu do członków Trybunału Roty Rzymskiej w dniu 30 stycznia 2003 roku podkreślił, że współcześnie można zaobserwować pewne istotne zjawisko, jakim jest u osób zawierających związek małżeński zatarcie

$4 \quad$ Katechizm Kościoła Katolickiego (dalej: KKK) 1623.

5 Paweł VI, encyklika Humanae vitae 8.

6 KKK 1601.

$7 \quad$ KKK 1661.

8 C. Rychlicki, Sakramentalny charakter przymierza chrześcijańskiego. Studium teologicznodogamtyczne, Płock 1997; M. Marczewski, Sakramentalność matżenstwa w ujęciu Jana Pawła II, [w:] Ku prawdzie we wspólnocie cztowieka i Boga. Studia dedykowane Ks. Stanistawowi Kowalczykowi, E. Balawajder, P. Nitecki, A. Jabłoński (red.), Sandomierz 1997 s. 479-484. 
się świadomości tego wszystkiego, co wynika z sakramentalności małżeństwa, a nawet jest to lekceważone. „Związek między laicyzacją, a kryzysem małżeństwa i rodziny jest aż nazbyt oczywisty. Kryzys wrażliwości na Boga oraz na dobro i zło moralne sprawia, że zanika wiedza o najgłębszych fundamentach małżeństwa i rodziny na nim opartej. Aby rzeczywiście ocalić świadomość prawdy w tej materii, należy na nowo odkryć wymiar transcendentny, stanowiący nieodłączny aspekt pełnej prawdy o małżeństwie i rodzinie, odrzucając wszelkie dychotomie, które prowadzą do oddzielenia aspektów świeckich od religijnych, jak gdyby istniały dwa odrębne małżeństwa: świeckie i sakralne"

Współczesna mentalność, w dużej mierze zlaicyzowana, skłonna jest afirmować ludzkie wartości rodziny, odrywając je od wartości religijnych. Podczas audiencji generalnej w dniu 29 kwietnia 2015 roku papież Franciszek postawił pytanie, dlaczego młodzi ludzie nie zawierają małżeństwa, dlaczego wolą tylko mieszkać razem i to niejednokrotnie z ograniczoną odpowiedzialnością, dlaczego nie pokładają ufności w rodzinie?

„W rzeczywistości prawie wszyscy mężczyźni i kobiety chcieliby mieć stałe poczucie bezpieczeństwa uczuciowego, trwałe małżeństwo i szczęśliwą rodzinę. Rodzina jest na pierwszym miejscu na wszystkich listach aspiracji ludzi młodych; lecz z obawy przed popełnieniem błędu wielu z nich nie chce nawet o niej myśleć; choć są chrześcijanami, nie myślą o małżeństwie sakramentalnym, jedynym i niepowtarzalnym znaku przymierza, który staje się świadectwem wiary. Być może właśnie ten lęk przed niepowodzeniem jest największą przeszkodą w przyjęciu słowa Chrystusa, który obiecuje swoją łaskę związkowi małżeńskiemu i rodzinie" ${ }^{10}$.

We współczesnym świecie zachodnim, ale częściowo i w społeczeństwie polskim, zaznaczają się coraz wyraźniej procesy desakralizacji małżeństwa i rodziny. W świadomości wielu katolików zaciera się sakramentalny charakter małżeństwa, co jest nawet widoczne u wielu nupturientów niedoceniających religijnego wymiaru swojego przyszłego małżeństwa. W społeczeństwach współczesnych rozwód jest nie tylko prawnie dopuszczalny, ale i społecznie akceptowany. Po rozwodzie poszukuje się na ogół nowego partnera, większość osób rozwiedzionych zawiera po raz wtóry formalny związek małżeński (cywilny).

Innym zjawiskiem jest odkładanie decyzji o zawarciu małżeństwa. W społeczeństwie polskim - jak wynika to z sondaży CBOS przeprowadzonych w latach 1996-2008 - zmieniły się przyczyny takich decyzji. Obecnie nie tyle trudności materialne czy problemy mieszkaniowe stanowią podstawowy powód przedłużającego się panieństwa czy kawalerstwa, ale raczej czynniki psychologiczne

„L ‘Osservatore Romano 24: 2003 nr 4 s. 48.

$10 \quad$ „L 'Osservatore Romano 36: 2015 nr 5 s. 48. 
oraz prowadzony tryb życia związany m.in. z pracą zawodową ${ }^{11}$. W ostatnim dwudziestoleciu podwyższył się przeciętny wiek nowożeńców o około 3 lata, do 26 lat u kobiet i 28 lat u mężczyzn, a także średni wiek urodzenia pierwszego dziecka o około 4 lata (do 27 lat) ${ }^{12}$.

W tym kontekście należy postawić pytanie o sakramentalny charakter małżeństwa w świadomości katolików polskich. Czy zgodnie z nauczaniem Kościoła katolickiego wierni rozumieją sakralny charakter małżeństwa? Czy rozumieją oni wystarczająco różnicę między religijnym i świeckim charakterem małżeństwa? Jakie planują zawrzeć małzeństwo: świeckie czy też w formie konkordatowej? Zarówno sondaże opinii publicznej, jak i badania socjologiczne $\mathrm{w}$ odniesieniu do tych kwestii są tylko nieliczne i prowadzone $z$ reguły w kontekście szerszej problematyki dotyczącej małżeństwa i rodziny.

Ogólna ocena ślubu kościelnego jest w społeczeństwie polskim bardzo wysoka. W międzynarodowym sondażu z 2008 roku aż 91,9\% badanych dorosłych Polaków deklarowało pogląd, że ważne jest religijne uświęcenie takiego wydarzenia jak małżeństwo, 92,8\% - narodziny dziecka i 94,2\% - śmierć i pogrzeb ${ }^{13}$. Bardzo wysoki poziom aprobaty ślubu kościelnego skonstatowano w sondażach ogólnopolskich, zrealizowanych przez Instytut Statystyki Kościoła Katolickiego SAC. W 1991 roku 2,9\% badanych deklarowało pogląd, że naprawdę ważny jest tylko ślub cywilny, 20,5\% - że ślub cywilny nie wystarcza, trzeba mieć także ślub kościelny, 45,2\% - że obydwa śluby są jednakowo ważne, 23,7\% - że naprawdę ważny jest tylko ślub kościelny, 2,7\% - że żaden ślub nie jest potrzebny, 5,0\% - trudno powiedzieć lub brak odpowiedzi; w 2012 roku (odpowiednio) - 3,2\%, 18,3\%, 37,9\%, 29,2\%, 8,8\%, 2,6\%. W latach 1991 2012 wskaźnik tych, którzy aprobowali wyłącznie ślub cywilny, lub odrzucali wszelką zinstytucjonalizowaną formę małżeństwa, zwiększył się od 5,6\% do 12,0\% (różnica 6,4\%) ${ }^{14}$.

W sondażu CBOS z lutego 2015 roku, przeprowadzonym na reprezentatywnej próbie losowej dorosłej ludności Polski, badani oceniali m.in. ważność niektórych praktyk religijnych, według skali od 1 - w ogóle nie jest ważna, do

11 R. Boguszewski, Kontrowersje wokót różnych zjawisk dotyczacych życia małżeńskiego i rodzinnego, „Komunikat z badań CBOS” 2008 nr 54 s. 1-6.

12 N. Hipsz, Spoleczne oceny alternatyw życia matżeńskiego, „Komunikat z badań CBOS” 2013 nr 32 s. 1; A. Kwak, Wspótczesny świat zmian - alternatywy dla matżeństwa, [w:] Kobiety i mężczyźni w „postrodzinnym” świecie, E. Paprzycka, J. Czernecka (red.), Łódź 2014 s. 5-19.

13 Kwestionariusz wywiadu EVS 2008 (Research International Pentor), [w:] Wartości i zmiany. Przemiany postaw Polaków w jednoczącej się Europie, A. Jasińska-Kania (red.), Warszawa 2012 s. 351.

14 W. Zdaniewicz, Model katolickiej religijności, [w:] Postawy spoteczno-religijne Polaków 1991-2012, L. Adamczuk, E. Firlit, W. Zdaniewicz (red.), Warszawa 2013 s. 121. 
7 - jest bardzo ważna. Według trzech stopni skali ceremonia chrztu została oceniona jako ważna przez 83,4\% badanych, ceremonia ślubu kościelnego - przez $81,1 \%$, ceremonia pogrzebu religijnego - przez $85,4 \%$ („nie jest ważna” według trzech stopni skali odpowiednio: 9,4\%, 11,4\%, 9,1\%). Pozostali respondenci wybierali wartość „4” (pośrednia między ważnością lub nieważnością lub byli niezdecydowani). W latach 2006-2015 nastąpiły niewielkie zmiany w aprobacie tzw. praktyk jednorazowych (chrzty, śluby, pogrzeby). Jako bardzo ważne lub raczej ważne w 2015 roku uznało o 4\% mniej w porównaniu z 2006 rokiem ceremonię chrztu, o 3\% - ceremonię ślubu i o 4\% - ceremonię pogrzebu. Znaczenie przypisywane tym ceremoniom spadało wraz z wielkością miejsca zamieszkania badanych osób, poziomem ich wykształcenia, dochodami per capita, a rosło wraz z częstością praktyk religijnych. Osoby w ogóle niepraktykujące przywiązywały zdecydowanie mniejszą wagę do ceremonii chrztu, ślubu, pogrzebu ${ }^{15}$.

Na nieco niższą rangę ślubu kościelnego wskazują wyniki badań dotyczących osób żyjących bez ślubu kościelnego. Według sondażu CBOS z lutego 2008 roku $19 \%$ badanych dorosłych Polaków prezentowało pogląd, że osoby żyjące razem bez ślubu bezwzględnie powinny zawrzeć małżeństwo, $41 \%$ - dobrze by było, gdyby osoby żyące ze sobą bez ślubu zdecydowały się na małżeństwo, 33\% - jeśli ludzie się kochają i ufają sobie, to nie ma znaczenia, czy żyją ze sobą w małżeństwie czy bez ślubu, 5\% - nawet jeśli ludzie się kochają i ufają sobie, to lepiej żeby nie zawierali małżeństwa, bo nigdy nie wiadomo, co może wydarzyć się w przyszłości i 2\% - trudno powiedzieć. Przekonanie o konieczności zawarcia małżeństwa przez osoby żyjące ze sobą bez ślubu wzrastało wyraźnie wraz $z$ wiekiem badanych oraz częstotliwością uczestnictwa w praktykach religijnych. Najbardziej liberalne w swoich opiniach były osoby będące w wieku 25-34 lat, mieszkające w największych miastach, legitymujące się wyższym wykształceniem, kadra kierownicza i inteligencja, osoby nieuczestniczące w praktykach religijnych, deklarujące lewicowe poglądy polityczne ${ }^{16}$.

Ponad połowa badanych przez CBOS dorosłych Polaków w lutym 2013 roku opowiadała się za formalizacją związków kohabitacyjnych (54\%), w tym 15\% było zdania, że osoby żyjące razem bez ślubu powinny bezwzględnie zawrzeć małżeństwo, a 39\% badanych uważało, że jest ono dobrym rozwiązaniem, jednak nie należy do niego nikogo zmuszać. Prawie dwie piąte ankietowanych wyrażało przekonanie, że jeśli ludzie się kochają i darzą zaufaniem, to status ich

15 Wyniki badania „Aktualne problemy i wydarzenia” (nr 297). Komunikat z badań CBOS (do użytku wewnętrznego), Warszawa 2015 s. 16; K. Kowalczuk, Sfery sacrum i profanum w życiu spolecznym, „Komunikat z badań CBOS” 2015 nr 31 s. 8-9.

16 R. Boguszewski, Kontrowersje wokót różnych zjawisk dotyczących życia matżeńskiego i rodzinnego, „Komunikat z badań CBOS” 2008 nr 54 s. 7-8. 
związku nie ma większego znaczenia (37\%). Nieliczni respondenci byli przeciwni legalizacji związków (5\%), bądź nie mieli zdania na ten temat (4\%). W latach 2008-2013 zmniejszył się nieznacznie od 60\% do 54\% wskaźnik optujących za formalizacją związków kohabitatycjnych oraz zwiększył się mających odmienne zdanie. Preferowaniu związków małżeńskich sprzyjało niższe wykształcenie, częstszy udział $\mathrm{w}$ praktykach religijnych i prawicowe poglądy polityczne, a w mniejszym stopniu starszy wiek i zamieszkiwanie w małej miejscowości ${ }^{17}$.

Polacy są podzieleni w swoich opiniach na temat ważności ślubu kościelnego i cywilnego. Według sondażu CBOS z lutego 2008 roku 5\% badanych dorosłych Polaków deklarowało, że ślub cywilny jest najważniejszy, ślub kościelny nie ma większego znaczenia, 27\% - wprawdzie ślub cywilny jest wystarczający, ale małżonkowie powinni zawrzeć również ślub kościelny, 33\% - najważniejszy jest ślub kościelny, który niesie ze sobą skutki prawne (tzw. konkordatowy), 32\% - rodzaj ślubu jest bez znaczenia, decyzja o nim powinna należeć do osób pobierających się, $0 \%$ - mający inne zdanie na ten temat, 3\% - trudno powiedzieć (w lutym 2013 roku odpowiednio: 9\%, 27\%, 28\%, 33\%, 1\%, 2\%). Wśród zwolenników ślubu kościelnego były przede wszystkim osoby starsze, o niższym wykształceniu, mieszkańcy wsi (zwłaszcza rolnicy) oraz osoby regularnie praktykujące ${ }^{18}$. W latach 2008-2013 zmniejszył się nieco odsetek zwolenników ceremonii nadających małżeństwu wyznaniową moc prawną (o 5 punktów) oraz przybyło osób uważających, że ślub cywilny jest najważniejszy (o 4 punkty) ${ }^{19}$.

Zróżnicowany jest poziom aprobaty ślubu kościelnego i cywilnego w środowiskach młodzieżowych. W badaniach młodzieży szkół średnich w Lublinie w 1997 roku ustalono dość wysoki poziom aprobaty ślubu kościelnego. W całej zbiorowości młodzieży szkolnej 64,3\% badanych wyraziło przekonanie, że małżeństwo wymaga zawarcia zarówno ślubu kościelnego jak i cywilnego, 13,3\% - że wystarczy tylko ślub kościelny, 13,6\% - że wystarczy tylko ślub cywilny, 8,3\% - że nie potrzeba żadnego ślubu i 0,6\% - to nieudzielający odpowiedzi. Pierwszą odpowiedź wybrało $69,5 \%$ badanych kobiet i 51,4\% - mężczyzn; $62,2 \%$ - urodzonych w wielkim mieście i 69,2\% - w mniejszych miastach lub na wsi; 72,9\% - legitymujących się pochodzeniem chłopskim, 72,4\% - pochodzeniem robotniczym i 55,4\% - pochodzeniem inteligenckim ${ }^{20}$.

17 N. Hipsz, Społeczne oceny alternatyw życia małżeńskiego, „Komunikat z badań CBOS” 2013 nr 32 s. 6-7.

18 R. Boguszewski, Kontrowersje wokót różnych zjawisk dotyczacych życia matżeńskiego i rodzinnego, „Komunikat z badań CBOS” 2008 nr 54 s. 9.

19 N. Hipsz, Społeczne oceny alternatyw życia matżeńskiego, „Komunikat z badań CBOS” 2013 nr 32 s. 8.

20 P. Brożek, Tradycja religijna w środowisku pluralistycznym. Studium socjologiczne, Lublin 2000 s. 97. 
Młodzież będąca w wieku 18-26 lat z woj. mazowieckiego i lubelskiego badana w latach 2004-2005 deklarowała pogląd, ze małżeństwo w nowoczesnym społeczeństwie ma i będzie mieć duże znaczenie (78,6\%), 6,8\% - że jest instytucją przestarzałą i 14,6\% - trudno powiedzieć. Zdecydowana większość młodzieży polskiej opowiadała się za małżeństwem od samego początku ze ślubem $(43,37 \%)$ lub za ślubem po jakimś czasie wspólnego mieszkania z partnerką/partnerem $(37,45 \%)$. Pozostali badani wyrażali następujące opinie: tego jeszcze nie wiem - 3,07\%; już jestem w związku - 0,67\%; nie chcę brać ślubu, ale chcę żyć i mieszkać razem z partnerka/partnerem - 8,99\%; chcę żyć sam/ sama bez partnera/partnerki - 4,72\%; brak odpowiedzi - 1,72\%. Kobiety częściej niż mężczýnini, osoby pochodzące z rodzin, w których matka legitymuje się niższym wykształceniem, częściej niż wykształceniem wyższym, osoby zdecydowanie religijne częściej niż raczej religijne lub niereligijne, osoby zdecydowanie pozytywnie oceniające związek małżeński rodziców częściej niż osoby mniej pozytywnie oceniające ten związek. W całej zbiorowości młodzieży 34,08\% badanych było za tym, aby małżeństwa i pary bez śluby miały te same prawa, $42,92 \%$ - było przeciw takiemu rozwiązaniu, $22,70 \%$ - to niezdecydowani i 0,30\% - nieudzielający odpowiedzi ${ }^{21}$.

Zdecydowana większość badanej młodzieży doceniała ważność ślubu kościelnego dla zawarcia małżeństwa: 51,99\% - dla mnie ślub kościelny ze względów religijnych jest ważniejszy niż ślub cywilny; 34,23\% - dla mnie ślub kościelny jest ważny, chociaż nie mam silnego związku z Kościołem; 10,71\% - dla mnie ślub kościelny/religijny jest niepotrzebny; 2,62\% - żadna z tych możliwości, nie chcę brać ślubu; 0,45\% - brak odpowiedzi. Ślub kościelny był o wiele ważniejszy dla kobiet niż mężczyzn, ważniejszy dla osób zdecydowanie religijnych niż raczej religijnych, tym mniej dla niereligijnych ${ }^{22}$. Można przypuszczać, że część młodego pokolenia młodych Polaków będzie zawierać ślub kościelny, kierując się motywami niereligijnymi (społeczno-kulturowymi).

Młodzież z województw kujawsko-pomorskiego, wielkopolskiego, małopolskiego i dolnośląskiego deklarowała w następujący sposób stosunek do ślubu: w przyszłości chcę żyć z partnerem tylko w związku małżeńskim - 33,88\%; najpierw chcę żyć i mieszkać z partnerką/partnerem, aby sprawdzić, czy ją/jego poślubić - 50,23\%; nie chcę brać ślubu, ale chcę żyć i mieszkać z partnerką/ partnerem - 4,38\%; chcę żyć sam/sama bez partnera/partnerki - 0,87\%; tego jeszcze nie wiem - 9,00\%; już jestem w związku małżeńskim - 1,64\%. Zdecydowana większość ankietowanej młodzieży pozytywnie oceniła znaczenie ślubu

\footnotetext{
21 L. Dyczewski, Wyobrażenia młodzieży o małzeństwie i rodzinie. Pomiędzy tradycją i nowoczesnościa, Lublin 2009 s. 77 i 101-110. 
kościelnego (dla mnie ślub kościelny ze względów religijnych jest ważniejszy niż ślub cywilny - 50,36\%; dla mnie ślub kościelny jest ważny, chociaż nie mam silnego związku z Kościołem - 35,13\%; dla mnie ślub kościelny/religijny jest niepotrzebny - 10,69\%; żadna z tych możliwości, nie chcę w ogóle brać ślubu $-3,82 \%)^{23}$.

Wśród studentów polskich w 2012 roku (próba ogólnopolska) tylko 6\% badanych uważało, że osoby żyjące ze sobą razem bezwzględnie powinny zawrzeć związek małżeński, $41 \%$ - że dobrze byłoby, gdyby takie osoby zalegalizowały swój związek, 45\% - że jeżeli ludzie się kochają, to formalny związek jest kwestią drugorzędną, 2\% - że małżeństwo to spore ryzyko, więc lepiej go nie zawierać, $5 \%$ - nie miało zdania na ten temat ${ }^{24}$.

Studenci pięciu uczelni lubelskich w latach 2011-2012 w rozmaity sposób oceniali wybrane katolickie normy moralne odnoszące się do małżeństwa i rodziny. W całej zbiorowości studentów lubelskich $66,9 \%$ badanych postrzegało swoją przyszłość życiową w związku małżeńskim, 7,9\% - w związku cywilnym (bez ślubu kościelnego), 4,8\% - w związku nieformalnym (bez ślubu kościelnego i cywilnego), 2,2\% - w luźnych spotkaniach z różnymi partnerami, 4,7\% - jako osoba samotna, $12,6 \%$ - trudno powiedzieć, 0,9\% - brak odpowiedzi; $61,0 \%$ badanych deklarowało, że zakładając rodzinę dwoje ludzi powinno zawrzeć tzw. ślub konkordatowy, 9,8\% - wystarczy ślub cywilny, 7,0\% - wystarczy ślub kościelny, 14,6\% - żaden ślub nie jest potrzebny, 6,7\% - trudno powiedzieć i 0,8\% - brak odpowiedzi; według 63,7\% badanych wspólne mieszkanie z partnerem przed ślubem kościelnym jest dozwolone, 19,4\% - to zależy od okoliczności, 10,8\% - niedozwolone, 5,4\% - trudno powiedzieć, 0,7\% - brak odpowiedzi $\mathrm{i}^{25}$.

Wśród gimnazjalistów z Kalisza i okolicznych miejscowości w latach 2001-2004 około dwie piąte badanych (38,0\%) akceptowało bez zastrzeżeń nierozerwalność i trwałość małżeństwa sakramentalnego, 18,1\% - częściowo akceptowało, 34,1\% - uznawało to za zbędne, 6,1\% - brak oceny (niezdecydowani), 3,7\% - brak odpowiedzi. Pogląd o nierozerwalności i dozgonnej trwałości związku małżeńskiego częściej prezentowali gimnazjaliści uczący się na wsi niż w mieście $(44,7 \%$ wobec $33,8 \%)$ oraz częściej dziewczęta niż chłopcy $(40,6 \%$ wobec $33,0 \%)^{26}$. W całej zbiorowości gimnazjalistów $41,1 \%$ badanych uznawało

23 T. Biernat, P. Sobierajski, Młodzież wobec matżeństwa i rodziny. Raport z badań, Toruń 2007 s. 64-65.

24 A. Guzik, R. Marzęcki, Ł. Stach, Pokolenie '89. Aksjologia i aktywność młodych Polaków, Kraków 2015 s. 150.

25 J.Kozak, Dziecipostmoderny? Studium socjologicznenad religijnością studentów, Sandomierz 2014 s. 435-440.

26 J. Baniak, Między buntem i sprzeciwem a potrzeba akceptacji izrozumienia. Kryzys tożsamości osobowej a świadomość religijna i moralna młodzieży gimnazjalnej. Studium socjologiczne, 
rozwody za dozwolone, 30,0\% - za niedozwolone, 15,2\% - to zależy, 9,6\% brak oceny i 4,1\% brak odpowiedzi; 23,8\% ankietowanych gimnazjalistów twierdziło, że koniecznym warunkiem ważności zawarcia małżeństwa jest przede wszystkim ślub cywilny, 57,7\% - ślub konkordatowy, 8,2\% - małżeństwo jest wyłącznie sprawą prywatną pary osób, które się kochają i chcą żyć wspólnie ze sobą, 6,8\% - brak oceny, 3,5\% - odpowiedzi; 24,8\% badanych zamierza zawrzeć tylko ślub cywilny, 49,7\% - ślub konkordatowy, 10,7\% - w ogóle nie zamierza zwierać ślubu, 11,3\% - brak oceny, 3,5\% - brak odpowiedzi ${ }^{27}$.

W świetle omówionych badań socjologicznych i sondaży opinii publicznej tylko około 15\% dorosłych Polaków uważało religijne uświęcenie związku małżeńskiego za sprawę nieważną (i być może tylko 10\% katolików), nieco więcej niż połowa badanych deklarowała pogląd, że osoby żyjące razem bez ślubu kościelnego powinny zawrzeć związek małżeński, trzecia część w tych sprawach pozostawiała decyzję osobom pobierającym się i tylko nieliczni preferowali wyłącznie ślub cywilny. W latach 2008-2013 zmniejszył się o około 5\% wskaźnik zwolenników ceremonii nadających małżeństwu wyznaniową moc prawną. W środowiskach młodzieżowych popularny jest pogląd aprobujący wspólne zamieszkanie partnerów przed ślubem (około 50\%). Pomimo stosunkowo wysokiej aprobaty ślubu kościelnego, w kwestiach szczegółowych jest wiele niekonsekwencji, a nawet niespójności w poglądach katolików polskich na temat małżeństwa i rodziny. Dotyczy to także rozumienia sakramentalnego charakteru małżeństwa.

\section{Sakramentalny charakter małżeństwa}

Mimo wysokich ocen dotyczących małżeństw zawieranych według formuły religijnej, coraz mniej nowożeńców decyduje się na ślub konkordatowy, a w niektórych wielkich miastach ceremonie świeckie odbywają się częściej niż wyznaniowe. W kwestiach szczegółowych związanych z zawarciem związku małżeńskiego poglądy Polaków są już bardziej zróżnicowane, a nawet do pewnego stopnia niespójne. Może to - przynajmniej pośrednio - wskazywać na fakt niezrozumienia tego, czym jest małżeństwo katolickie, a zwłaszcza tego, co oznacza sakramentalny charakter małżeństwa. Badania socjologiczne nad świadomością sakramentalną małżeństwa są nieliczne, a ich wyniki nie są w pełni konkluzyjne. Poniżej omawiamy je w skrótowej formie.

Młodzieży ze szkół ogólnokształcących, techników i liceów zawodowych, z różnych regionów Polski, postawiono w ankiecie pytanie, jak rozumieją oni

Kraków 2008 s. 408.

27 Ibidem s. 410 i 421-422. 
twierdzenie, że małżeństwo jest sakramentem. W kafeterii pytania zamieszczono różne religijne aspekty sakramentalności związku małżeńskiego. Badanej w latach 1997-2000 młodzieży szkolnej z sakramentalnością związku małżeńskiego kojarzyła się przede wszystkim jego nierozerwalność, czyli coś, co jest przede wszystkim konsekwencją sakramentalności małżeństwa (od 46,3\% do $67,2 \%$ w poszczególnych środowiskach młodzieżowych w różnych miastach). Około piąta część ankietowanych wybrała odpowiedź: „oznacza zaproszenie Pana Boga do małżeństwa i rodziny” (od 16,0\% do 28,2\%), „mężczyzna i kobieta tworzą razem część Kościoła” (od 14,7\% do 31,0\%), „Chrystus daje małżonkom specjalną łaskę" (od 10,8\% do 32,8\%). Przynajmniej co dziesiąty badany nie rozumiał tego wyrażenia lub nie miało ono dla niego żadnego znaczenia (od 5,8\% do 16,2\%). Jeżeli uznać za właściwą odpowiedź, że sakramentalność małżeństwa oznacza specjalną łaskę daną małżonkom przez Boga, to jedynie zdecydowana mniejszość ankietowanej młodzieży szkolnej prawidłowo interpretowała zdanie, że małżeństwo jest sakramentem. Ponad połowa respondentów utożsamiała sakramentalność małżeństwa z jego nierozerwalnością, znaczna część wybierała ogólnikowe i mgliste określenia, wskazujące na jakąś „sakralność" małżeństwa, ale nie na jego sakramentalność.

Kobiety nieco częściej niż mężczyźni rozpoznawały prawidłowo sakramentalny związku małżeńskiego (23,8\% wobec 18,7\%), młodzież szkół ogólnokształcących częściej niż szkół technicznych (24,5\% wobec 17,9\%), uczniowie klas pierwszych rzadziej niż klas maturalnych $(17,7 \%$ wobec $25,4 \%)$, młodzież mieszkająca na wsi nieco częściej niż mieszkająca w wielkich miastach $(23,7 \%$ wobec $20,4 \%$ ), osoby głęboko wierzące częściej niż niewierzące (23,5\% wobec 7,0\%), osoby bardzo regularnie praktykujące częściej niż w ogóle niepraktykujące $(27,6 \% \text { wobec } 10,8 \%)^{28}$.

Maturzyści z diecezji siedleckiej na postawione w ankiecie pytanie: czym jest dla ciebie sakrament małżeństwa, udzielili następujących odpowiedzi: trwały związek - 47,78\% ogółu badanych, połączenie dwóch osób w jedną - 19,66\%, odpowiedzialna decyzja - 14,32\%, początek rodziny - 5,08\%, nie uznaję tego sakramentu $-1,76 \%$, związek mało istotny $-4,39 \%$, inna odpowiedź $-6,58 \%$, brak odpowiedzi - 0,43\%. Sakramentalna instytucja małżeństwa wydaje się w świadomości maturzystów diecezji siedleckiej czymś ważnym i odpowiedzialnym w kontekście planowania osobistego życia. Równocześnie jednak tylko 26,56\% badanych maturzystów nie akceptuje antykoncepcji i 47,93\% - związków małżeńskich pozasakramentalnych ${ }^{29}$.

28 J. Mariański, Sekularyzacja i ewangelizacja. Wartości prorodzinne w świadomości młodzieży szkót średnich, Lublin 2003 s. 390-391.

29 M.Z. Stepulak, Postawy mtodzieży wobec mitości, matżeństwa i rodziny. Badania empiryczne maturzystów z diecezji siedleckiej, „Teologia Praktyczna” 8: 2007 s. 142-144. 
W zbiorowości studentów dziennikarstwa Uniwersytetu Kardynała Stefana Wyszyńskiego (UKSW) i Uniwersytetu Warszawskiego (UW) 26,69\% badanych deklarowało, że do ważności małżeństwa konieczny jest ślub kościelny, tak naprawdę tylko on jest ważny; według 32,02\% - zawarcie ślubu kościelnego i cywilnego; według 20,22\% - wystarczy tylko ślub cywilny; według $15,17 \%$ żaden ślub nie jest potrzebny; według 5,62\% - trudno powiedzieć (0,28\% - brak odpowiedzi). Zróżnicowane były wypowiedzi studentów na temat znaczenia małżeństwa jako sakramentu. W całej zbiorowości studentów $8,43 \%$ badanych deklarowało, że sakrament małżeństwa znaczy to, iż mąż i żona są włączeni do Kościoła, 23,31\% - że oznacza nierozerwalność małżeństwa, 44,94\% - że małżonkowie otrzymują od Chrystusa specjalną łaskę, 13,76\% - nic dla mnie nie znaczy, 3,37\% - w ogóle nie rozumiem tego zdania, 5,63\% - inne określenia (np. dar Ducha Świętego, małżeństwo jest objawieniem się Boga, małżonkowie stają się jednym ciałem i duszą), 0,50\% - brak odpowiedzi. Studenci UKSW znacznie częściej niż studenci UW deklarowali, że w sakramencie małżeństwa zawierający małżeństwo otrzymują od Chrystusa specjalną łaskę (54,35\% wobec 38,99\%). Z kolei dla 21,56\% studentów UW i 1,45\% studentów UKSW twierdzenie, że małżeństwo jest sakramentem, nic nie znaczy ${ }^{30}$.

Wśród uczestników kursów przedmałżeńskich w 2013 roku w Białymstoku 47,9\% badanych wybrało odpowiedź, że małżeństwo to sakrament, który umacnia wiarę i zbliża do Boga. Częściej wybierano odpowiedź: jestem katolikiem $69,5 \%$, nie wyobrażam sobie inaczej, to wewnętrzna potrzeba - 56,8\%, rzadziej zaś deklarowano: chęć katolickiego wychowania dzieci - 28,9\%, gwarancja trwałości związku - 14,3\%, tradycja i nacisk rodziny - 9,9\%, nacisk partnera lub otoczenia - 1,6\%, podoba mi się zewnętrzna forma ceremonii w kościele $-4,0 \%$, strach przed skandalem z powodu ciąży - 0,5\% ${ }^{31}$. W zbiorowości nupturientów w 2014 roku 57,5\% badanych w Polsce (Lublin) i 36,7\% - w Anglii i Walii deklarowało, że chce zawrzeć ślub kościelny, bo jest to sakrament, który umacnia wiarę i zbliża do Boga. Ten motyw zawarcia kościelnego związku małżeńskiego częściej deklarowały kobiety, osoby praktykujące, pochodzące $z$ małych miejscowości i osoby o niższym poziomie wykształcenia ${ }^{32}$.

Zebrane dane empiryczne wskazują, że część młodzieży polskiej zawiera ślub kościelny, nie w pełni rozumiejąc jego naturę sakramentalną, a nawet kierując

30 B. Więckiewicz, Małżeństwo i rodzina w świadomości mtodzieży akademickiej. Stacjonarni studenci dziennikarstwa UKSW $i$ UW (w druku).

31 K. Kamiński, Małzeństwo i rodzina w świadomości nupturientów. Studium socjologiczne, Lublin 2015 (mps pracy doktorskiej) s. 171.

32 J. Kozak, Rodzina w kryzysie? Esej socjologiczny z racji 120-lecia istnienia Polskiej Misji Katolickiej w Anglii i Walii nad modelami małżeństwa i rodziny w świadomości nupturientów, Lublin 2015. 
się motywami pozareligijnymi. Kościół katolicki w Polsce stawia dość wysokie wymagania osobom chcącym zawrzeć religijny związek małżeński: kursy przygotowawcze do małżeństwa, odbycie spowiedzi przed ślubem kościelnym i przyjęcie Komunii św. podczas ceremonii ślubnej. Zapewne część osób zawierających ślub kościelny nie respektuje wewnętrznie tych wymogów, a nie mając odpowiednich dyspozycji do przyjęcia sakramentu małżeństwa, naruszają oni nie tylko dyscyplinę kościelną, ale i narażają się na niebezpieczeństwo znieważenia swojej wiary.

Niedostatki w rozumieniu sakramentalności związku małżeńskiego nie muszą rzutować na ogólną ocenę związku małżeńskiego zawieranego w Kościele. Nawet osoby nierozumiejące do końca, czym jest małżeństwo sakramentalne, mogą cenić bardzo wysoko ślub kościelny i uważać go za nieodzowny do zaistnienia właściwego związku małżeńskiego. Także uznanie rozwodu, choć jest naruszeniem rygoryzmu kościelnego w zakresie bezwarunkowej nierozerwalności sakramentalnego małżeństwa, nie oznacza ipso facto uznania małżeństwa cywilnego za normalne małżeństwo, kwalifikowane na równi z małżeństwem kościelnym. Dla części ludzi współczesnych ani instytucje kościelne, ani państwowe nie powinny mieć wpływu na życie małżeńskie. Kwestionowanie oficjalnego zawarcia związku małżeńskiego w kościele, czy jego społeczne usankcjonowanie „zmienia się jednak najczęściej, kiedy w związku dwojga osób narodziło się, czy ma się narodzić dziecko. Ślub jest wtedy nie tylko obrzędem zawarcia małżeństwa, co jednocześnie obrzędem założenia rodziny"33.

Na tle dość daleko posuniętej w społeczeństwie polskim aprobaty rozwodów ponad 60\% badanych Polaków zareagowało aprobatą ślubu kościelnego jako elementu koniecznego do zawarcia małżeństwa, ale wyłączność ślubu kościelnego dla zaistnienia związku małżeńskiego akceptuje już tylko mniejszość ankietowanych. Aprobata w jakiejś formie ślubu kościelnego nie zawsze musi oznaczać uznanie modelu rodziny opartego na nierozerwalnym związku małżeńskim, i to sakramentalnym. Dla pewnej części ludzi młodych, określających się jako wierzący, zawarcie sakramentalnego związku małżeńskiego ma powierzchowny charakter, niezakotwiczony w sacrum. W tym punkcie nasuwa się pytanie o poziom kursów przedmałżeńskich i ich skuteczność oddziaływania na nupturientów. Przytoczone powyżej fragmentaryczne wyniki z badań socjologicznych sugerują, że poziom wiedzy na temat sakramentalnego charakteru małżeństwa, zarówno wśród nupturientów jak i wśród samych małżonków, nie jest zbyt wysoki ${ }^{34}$.

33 M. Polak, Społeczno-kulturowe uwarunkowania duszpasterstwa narzeczonych, „Teologia Praktyczna" 2(2001), s. 113.

34 ORRK: jak pomagać parom niesakramentalnym? „Wiadomości KAI” 2015 nr 17 s. 10-11. 


\section{Dopuszczanie do Komunii eucharystycznej osób żyjących w związkach niesakramentalnych}

Problem dopuszczenia do Komunii św. osób żyjących w związkach niesakramentalnych jest niezwykle delikatny i złożony, do pewnego stopnia palący, ze względu na wzrastającą liczbę rozwodów w dzisiejszych społeczeństwach, także w kręgach katolickich. W adhortacji apostolskiej Sacramentum caritatis z 2007 roku papież Benedykt XVI potwierdził praktykę Kościoła „niedopuszczania do sakramentów osób rozwiedzionych, które zawarły nowe związki, ponieważ swoim stanem i sytuacją życiową obiektywnie sprzeciwiają się tej jedności w miłości pomiędzy Chrystusem i Kościołem, która jest oznaczona i realizowana w Eucharystii. Niemniej jednak osoby rozwiedzione, które zawarły ponowne związki, nadal - pomimo ich sytuacji - przynależą do Kościoła, który ze szczególną troską im towarzyszy w ich pragnieniu kultywowania, na tyle na ile to jest możliwe, chrześcijańskiego stylu życia" ${ }^{35}$, poprzez uczestnictwo we Mszy św., choć bez przyjmowania Komunii św., słuchanie słowa Bożego, adorację eucharystyczną, modlitwę, uczestnictwo w życiu wspólnotowym, szczerą rozmowę z kapłanem czy ojcem duchownym, oddawanie się czynnej miłości, dziełom pokuty oraz zaangażowaniu w wychowanie dzieci ${ }^{36}$.

Kościół katolicki w urzędowych dokumentach potwierdzał wielokrotnie swoją praktykę, opartą na Piśmie Świętym i Tradycji, niedopuszczania do Komunii eucharystycznej rozwiedzionych, którzy zawarli ponowny związek małżeński. Dopuszczenie ich do Eucharystii wprowadzałoby wiernych w błąd i powodowałoby zamęt co do nauki Kościoła o nierozerwalności małżeństwa. Zakaz ten dotyczy zarówno tych, którzy usiłowali ocalić pierwsze małżeństwo lub zostali całkowicie niesprawiedliwie porzuceni, jak i tych, którzy z własnej ciężkiej winy zniszczyli ważne kanonicznie zawarte małżeństwo. Według Katechizmu Kościoła Katolickiego: „Nie mogą one jednak otrzymać sakramentalnego rozgrzeszenia ani przystępować do Komunii eucharystycznej, ani też pełnić pewnych funkcji kościelnych tak długo, jak długo trwa ta sytuacja, która obiektywnie wykracza przeciw prawu Bożemu"37.

Gdy mężczyzna i kobieta, którzy dla ważnych powodów (np. wychowania dzieci) nie mogą się rozstać, ale postanawiają żyć w pełnej wstrzemięźliwości, czyli powstrzymywać się od aktów, które przysługują jedynie małżonkom, wówczas mogą przystąpić do sakramentu pokuty, bowiem są gotowi na taką formę życia, która nie stoi w sprzeczności z nierozerwalnością małżeństwa. Kościół

\footnotetext{
35 Benedykt XVI, adhortacja apostolska Sacramentum caritatis 29.

36 Ibidem.

$37 \quad$ KKK 349.
} 
nie potępia osób żyjących w związkach niesakramentalnych, nie wyłącza ich ze swojej wspólnoty, zachęca nawet do życia w wierze i miłości chrześcijańskiej, ale podtrzymuje swój sprzeciw wobec ich ewentualnego udziału w Komunii św. Z jednej strony mamy więc dobro wspólnoty i sakramentu, które Kościół chce uszanować, z drugiej strony dostrzega cierpienie osób, którym chce pomóc. Takie stanowisko jest swoistym balansowaniem między „rygoryzmem” prawa kanonicznego i miłosierdziem wobec grzesznego człowieka.

W niektórych krajach zachodnioeuropejskich, być może częściowo i w Polsce, osoby rozwiedzione żyjące w nowych związkach małżeńskich, przystępują do Komunii św., nie licząc się z przykazaniami Boskimi i kościelnymi. Być może towarzyszy temu ciche przyzwolenie osób duchownych, które chcą praktykować chrześcijaństwo z łagodniejszą, życzliwą i bardziej tolerancyjną twarzą, a nawet dążą do wprowadzenia w Kościele zmian doktrynalnych. Także niektórzy teologowie stawiają pytanie, czy słowa Jezusa na temat nierozerwalności małżeństwa stanowią precyzyjną normę moralną absolutnie wiążącą (węzeł małżeński nie może być nigdy rozwiązany i nowe małżeństwo jest wykluczone), czy też należy je traktować jako wezwanie do pełni ideału etycznego, bez utożsamienia z prawem uniezdalniającym ${ }^{38}$. Z ideału nie można czynić - twierdzi się - absolutnego prawa.

W społeczeństwie polskim obserwujemy znaczne zmiany w świadomości społecznej dotyczącej trwałości małżeństwa. Nie dysponujemy danymi statystycznymi, które w sposób precyzyjny określałyby liczbę osób żyjących w powtórnych związkach małżeńskich (bez ślubu kościelnego). Według niektórych szacunków ponad 540 tys. polskich par żyje w konkubinatach ${ }^{39}$. Z sondażu CBOS z 2008 roku wynika, że spośród ogółu dorosłych Polaków co jedenasty (9\%) przyznawał, że niezależnie od swojego stanu cywilnego żyje z kimś w związku nieformalnym (partnerskim), częściej młodsi wiekiem respondenci, mieszkańcy wielkich miast, uczniowie i studenci, osoby z wyższym wykształceniem, lepiej usytuowani materialnie, nieuczestniczący w praktykach religijnych ${ }^{40}$.

W świetle danych empirycznych wskazujących na znaczną gotowość aprobowania zmiany dotychczasowego ustawodawstwa kościelnego wobec rozwodów (szeroka społeczna aprobata rozwodów) można spodziewać się daleko idącej aprobaty zmian ustawodawstwa kościelnego, zabraniającego przystępowania do sakramentów osobom pozostającym w związkach małżeńskich

38 S. Pławecki, Rozwiedzeni żyjący w powtórnych zwiazkach jakoproblem moralno-duszpasterski, [w:] Nadzieje i zagrożenia wspótczesnej rodziny. Międzynarodowe sympozjum moralno-pastoralne Kraków 1994, W. Kawecki (red.), Warszawa 1995 s. 104 i 122.

39 P. Drąg, Należy troszczyć się o zwykłe matżeństwa, „Wiadomości KAI” 2015 nr 16 s. 6.

40 R. Boguszewski, Kontrowersje wokót różnych zjawisk dotyczących życia matżeńskiego i rodzinnego, „Komunikat z badań CBOS” 2008 nr 54 s. 6. 
niesakramentalnych. Badania socjologiczne dotyczące kwestii dopuszczenia do Komunii św. osób żyjących w związkach niesakramentalnych są nieliczne i były realizowane głównie w środowiskach młodzieżowych.

Na początku lat dziewięćdziesiątych XX wieku znaczna część badanych mieszkańców wielkich i małych miast deklarowała opinie, według których Kościół katolicki powinien przyznać prawo przystępowania do Komunii św. rozwiedzionym katolikom, którzy zawarli powtórne małżeństwo. W badaniach realizowanych przez Katedrę Socjologii Rodziny i Wychowania KUL 81,7\% badanych z Warszawy, 77,5\% - z Leżajska, 72,5\% - z Iłży, 63,5\% - z Ostrowa Lubelskiego i 59,2\% - studentów lubelskich opowiadało się za prawem osób żyących w powtórnych związkach małżeńskich do przystępowania do Komunii św. Tylko 9,4\% badanych z Warszawy i po dwadzieścia kilka procent badanych $z$ innych zbiorowości wyraźnie odmawiało im tego prawa. Można przypuszczać, że większość z tych badanych osób uważała także, że Kościół katolicki powinien dopuścić rozwody, a także przyznać prawo do zawarcia powtórnego małżeństwa po rozpadzie pierwszego związku małżeńskiego ${ }^{41}$.

Wśród młodzieży szkolnej w latach 1997-2000, w siedmiu miastach polskich (Jastrzębie Zdrój, Chełm, Rzeszów, Lublin, Gdańsk, Poniatowa, Ryki), od 13,1\% do 23,8\% badanych poparło zdecydowanie postulat dopuszczenia osób pozostających w związkach małżeńskich bez ślubu kościelnego do sakramentów, od $19,7 \%$ do $26,6 \%$ - raczej tak, od $9,6 \%$ do $19,5 \%$ - raczej nie, od $10,3 \%$ do $12,9 \%$ - zdecydowanie nie, od $21,1 \%$ do $34,5 \%$ - brak zdania i od 3,0\% do $6,9 \%$ - brak odpowiedzi. Około dwóch piątych badanych we wszystkich miastach prezentowało pogląd, że Kościół w swoich rozwiązaniach pastoralnych powinien być bardziej elastyczny. Za liberalizacją stanowiska Kościoła w podobny sposób opowiadali się mężczyźni i kobiety, młodzież z różnych typów szkól, z klas pierwszych i maturalnych, nieco częściej młodzież z wielkich miast niż z mniejszych miejscowości. Cechy religijne wyraźniej różnicowały opinie badanej młodzieży niż cechy demograficzne i społeczne ${ }^{42}$.

Zbliżone wyniki empiryczne uzyskano w innych badaniach socjologicznych. W Lublinie w 1994 roku 21,4\% respondentów zdecydowanie zgadzało się $z$ twierdzeniem, że Kościół katolicki powinien dopuścić do sakramentów osoby pozostające w związkach małżeńskich bez ślubu kościelnego, 26,9\% - raczej tak, $14,0 \%$ - raczej nie, $10,3 \%$ - zdecydowanie nie, $24,7 \%$ - trudno powiedzieć, 2,6\% - brak odpowiedzi; w 2005 roku (odpowiednio): 21,8\%, 22,2\%, $17,5 \%, 9,2 \%, 26,2 \%, 3,1 \%$. W latach $1994-2005$ opinie i poglądy badanych

\footnotetext{
$41 \quad$ P. Kryczka, Rozwód w opinii społecznej, „Studia Socjologiczne” 1999 nr 1 s. 53.

42 J. Mariański, Sekularyzacja i ewangelizacja. Wartości prorodzinne w świadomości mtodzieży szkót średnich, Lublin 2003 s. 308-310.
} 
maturzystów na temat dopuszczenia do sakramentów osób żyjących w związkach małżeńskich niesakramentalnych nie uległy zmianie (badania Emilii Żerel). Wśród maturzystów z Lublina w roku szkolnym 2009/2010 odpowiedzi kształtowały się następująco: 18,3\%, 28,2\%, 19,7\%, 10,9\%, 21,4\%, 1,5\% (badania Marcina Roli). W Lublinie w 2005 roku 44,0\% badanych maturzystów i w 2010 roku - 46,5\% wysuwało postulaty sprzeczne z nauczaniem moralnym Kościoła katolickiego.

Maturzyści z pięciu miast (Szprotawa, Puławy, Kraśnik, Dęblin, Gdańsk) w 2009 roku oceniali twierdzenie, że Kościól powinien dopuszczać do sakramentów osoby pozostające w związkach małżeńskich bez ślubu kościelnego. W całej zbiorowości młodzieży 21,1\% odpowiedziało, że zdecydowanie zgadza się, 27,3\% - raczej zgadza się, 17,0\% - raczej nie zgadza się, 9,8\% - zdecydowanie nie zgadza się, 23,8\% - trudno powiedzieć i 1,0\% - brak odpowiedzi; w 1994 roku odpowiednio 20,4\%, 30,5\%, 12,7\%, 7,3\%, 27,3\%, 1,9\%. W latach 1994-2009 nie nastąpiły zmiany w poglądach maturzystów, utrzymywały się one $\mathrm{w}$ omawianej sprawie na względnie stabilnym poziomie.

W 2009 roku 48,4\% badanych maturzystów prezentowało pogląd, że Kościół katolicki w swoich rozwiązaniach pastoralnych powinien być bardziej wyrozumiały i elastyczny, zdecydowanie mniej spośród nich deklarowało stanowisko odmienne. Postulaty złagodzenia dyscypliny kościelnej w omawianej sprawie nieco częściej zgłaszały kobiety, młodzież z liceów ogólnokształcących, osoby mieszkające $w$ wielkich miastach i luźno związane z religią. Warto jeszcze dodać, że tylko 19,9\% badanych maturzystów akceptowało twierdzenie, że Kościół powinien zdecydowanie przeciwstawiać się stosowaniu środków antykoncepcyjnych, 49,6\% - że Kościół nie powinien ustępować w swoim potępianiu przerywania ciąży i 48,4\% - że Kościół powinien zliberalizować swoją postawę wobec rozwodów ${ }^{43}$.

Wielu Polaków oczekuje zmian w nauczaniu i dyscyplinie Kościoła katolickiego. W całej zbiorowości dorosłych Polaków w lutym 2005 roku - według sondażu CBOS - 79,6\% badanych deklarowało pogląd, że Kościół katolicki powinien umożliwić osobom rozwiedzionym, które wstąpiły w ponowny związek małżeński, przystępowanie do Komunii św. (odpowiedzi „zdecydowanie tak” i „raczej tak”); 68,9\% - że powinien uprościć procedury uznawania związku małżeńskiego za nieważny (ułatwić tzw. rozwody kościelne); 32,1\% - umożliwić osobom będącym w związkach homoseksualnych przystępowanie do Komunii św.; 15,9\% - dopuścić osoby będące w związkach homoseksualnych

43 Idem, Oczekiwania maturzystów polskich wobec Kościoła katolickiego, [w:] Rodzinaw prawie. Księga pamiatkowa dedykowana ks. prof. dr. hab. Ryszardowi Sztychmilerowi z okazji 65. rocznicy urodzin i 30-lecia pracy naukowej, M. Różański, J. Krzywkowska (red.), Olsztyn 2013 s. 243-244. 
do sakramentu małżeństwa; 71,6\% - przyzwolić na stosowanie środków antykoncepcyjnych; 72,8\% - dopuścić możliwość przerywania ciąży w niektórych sytuacjach; 78,9\% - dopuścić możliwość korzystania z zapłodnienia pozaustrojowego in vitro przez niepłodne małżeństwa; 58,3\% - znieść celibat; 60,0\% zastąpić spowiedź indywidualną spowiedzią powszechną (zbiorową) podczas Mszy św.; 37,0\% - dopuścić kobiety do sakramentu kapłaństwa ${ }^{44}$. Zgłaszane przez znaczną część Polaków, w tym i katolików, postulaty czy oczekiwania stoją w sprzeczności z nauczaniem i praktyką Kościoła katolickiego.

Cechy demograficzne i społeczne różnicują tylko nieznacznie deklarowane postulaty zgłaszane przez badanych Polaków, dotyczące zmian w Kościele katolickim. Cechą najbardziej różnicującą te opinie są realizowane praktyki religijne, ale i wśród praktykujących mniej lub bardziej regularnie zgłaszane są postulaty zmian w nauczaniu i praktyce Kościoła. Wśród uczestniczących raz w tygodniu w praktykach religijnych $77 \%$ badanych uważało, że Kościół powinien umożliwić osobom rozwiedzionym, które ponownie wstąpiły w związek małżeński, przystępowanie do Komunii św.; 72\% - dopuścić możliwość korzystania z procedur in vitro; 64\% - dopuścić możliwość przerywania ciąży w niektórych sytuacjach; $61 \%$ - przyzwolić na stosowanie środków antykoncepcyjnych; 63\% - uprościć procedurę uznawania związku małżeńskiego za nieważny; 57\% - zastąpić spowiedź indywidualną spowiedzią powszechną; 49\% - znieść celibat; 27\% - dopuścić kobiety do sakramentu kapłaństwa; 21\% umożliwić osobom będącym w związkach homoseksualnych przystępowanie do Komunii św.; 8\% - dopuścić osoby będące w związkach homoseksualnych do sakramentu małżeństwa; wśród tych, którzy deklarowali się jako głęboko wierzący, odpowiednio: 52\%, 54\%, 45\%, 32\%, 44\%, 37\%, 38\%, 16\%, 15\%, 7\% ${ }^{45}$.

„Badania socjologiczne nie dają odpowiedzi na pytanie, czy i w jakiej mierze Kościół wychodząc naprzeciw oczekiwaniom wiernych powinien się zmieniać. Niemniej jednak dostarczają danych do diagnozy sytuacji Kościoła rozumianego jako wspólnota wiernych i stanowią dobry punkt wyjścia do ewentualnej dyskusji na ten temat. Badania CBOS wskazują na postępujący rozdźwięk między nauczaniem Kościoła a postawami ludzi [...]. Nic zatem dziwnego, że większość Polaków, wśród nich także znaczna część najbardziej zaangażowanych religijnie, opowiada się za zmianami w nauczaniu Kościoła dotyczącymi rodziny. Wypowiedzi i konkretne inicjatywy papieża Franciszka, w tym przede wszystkim synody (ubiegłoroczny i planowany na ten rok) poświęcone wyzwaniom duszpasterskim dla rodzin, skłaniają wiele osób do przekonania, że podczas obecnego

44 Wyniki badania „Aktualne problemy i wydarzenia” (nr 297). Komunikat z badań CBOS (do użytku wewnętrznego). Warszawa 2015 s. 14-16.

45 B. Roguska, Oczekiwane zmiany w nauczaniu Kościoła, „Komunikat z badań CBOS” 2015 nr 32 s. 8-9. 
pontyfikatu rzeczywiście zostaną wprowadzone istotne zmiany w nauczaniu Kościoła. Sam papież jest dobrze odbierany przez zdecydowaną większość Polaków, dla znacznej ich liczby, w tym także osób, które słabo identyfikują się z Kościołem, stanowi ważny autorytet moralny"46.

Uzyskane wyniki empiryczne świadczą o tym, że znaczna część młodzieży i ludzi dorosłych sądzi, iż z Kościołem jako instytucją można dyskutować na temat jego nakazów i zakazów, zwłaszcza tych, które bezpośrednio ingerują w życie osobiste człowieka. Te tendencje „demokratyzacyjne” i „modernizacyjne" mogą tworzyć pole konfliktu w zderzeniu się z instytucją, która z założenia jest hierarchiczna, a przynajmniej do zwiększania się postaw krytycznych, selektywnych czy wybiórczych wobec doktryny Kościoła katolickiego. Niektórzy twierdzą, że ze względu na współczucie i miłosierdzie, a także ze względu na niebezpieczeństwo odpływu wiernych z Kościoła, należy zmodyfikować rygorystyczną doktrynę moralną Kościoła w odniesieniu do osób żyjących w związkach niesakramentalnych ${ }^{47}$.

Dane socjologiczne nie rozstrzygają kwestii dogmatycznych czy moralnych Kościoła katolickiego, jedynie sygnalizują problemy i ukazują ich społeczne rozmiary. Dowodzą także, że wiele osób żyjących w zrekonstruowanych związkach małżeńskich oddala się od Kościoła, a w konsekwencji przestaje na co dzień praktykować wiarę. Dla Kościoła jest to poważny problem pastoralny, gdyż z jednej strony uznaje on, że dla ludzi ochrzczonych istnieje jedynie małżeństwo sakramentalne, a każde jego naruszenie jest niezgodne z wolą Boga, ale $z$ drugiej strony ma świadomość słabości wielu swoich członków, którzy $z$ trudem podążają drogą przykazań wiary. Wierni ci należą w dalszym ciągu do Kościoła, potrzebują miłosiernego i dodającego otuchy zainteresowania duszpasterskiego ${ }^{48}$.

Według niektórych badaczy, np. psychologa Józefa Kozieleckiego, jeżeli Kościół katolicki w Polsce nie przystosuje się do wymogów współczesnej cywilizacji i do preferencji młodego pokolenia i będzie obstawał przy zbyt rygorystycznych rozwiązaniach dotyczących m.in. życia seksualnego, zapłodnienia in vitro, aborcji, wówczas wielu młodych ludzi w naszym kraju będzie poszukiwać celowości życia i samorealizacji w innych wyznaniach i religiach, bardziej liberalnych

$46 \quad$ Ibidem s. 10.

47 Zdrowe małzeństwa trzeba umacniać. Rozmowa z księdzem arcybiskupem Stanisławem Gądeckim, metropolita poznańskim, przewodniczacym KEP. „Nasz Dziennik” 2015 nr 101 s. 13.

48 M. Kawińska, Rodzina i zwiazki niesakramentalne we wspólnocie parafialnej - kierunki przemian, [w:] Socjologia życia parafialnego: wspólnota i instytucja. Archidiecezja Warszawska w badaniach Polskiego Pomiaru Postaw $i$ Wartości, S. H. Zaręba, A. Wysocki (red.), Warszawa 2015, s. 18. 
i permisywnych, jak np. buddyzm czy hinduizm. Powstaną nowe ruchy kultowe, nowe religie, które już obecnie stymulują wyobraźnię młodzieży polskiej, albowiem odgrywają one znaczną rolę osobowościowo-twórczą ${ }^{49}$.

Leszek Kołakowski z kolei wskazuje na nieumiejętność znalezienia przez Kościół języka, który trafiałby do ludzi wykształconych i młodych. „Jeśli proces ten będzie się pogłębiał, możemy stać się świadkami odchodzenia rzesz ludzi od Kościoła oraz chrześcijaństwa i angażowania się ich w inne formy życia religijnego, już istniejące albo nowe" ${ }^{50}$. Jeżeli nawet przytoczone prognozy i przestrogi są nieco wyolbrzymione, to nie należy ich całkowicie lekceważyć. Są one zachętą do refleksji nad sposobami i formami upowszechniania doktryny moralnej Kościoła.

Kościół katolicki w Polsce jest postrzegany przez większość jako wspólnota ludu Bożego, ale znaczna część katolików doświadcza go przede wszystkim jako instytucję zaspokajającą potrzeby religijne wiernych. Postawy wielu polskich katolików wobec Kościoła są nacechowane swoistą ambiwalencją. Większość z nich, co prawda, odznacza się pewną życzliwością wobec Kościoła, inni nastawieni są sceptycznie, jeszcze inni reagują obojętnością i brakiem zainteresowania. Wydaje się, że w ostatnich latach przybywa tych, którzy mniej lub bardziej wyraźnie dystansują się od jego doktryny społecznej i moralnej, aż po rosnącą liczbę tych, którzy formalnie opuszczają Kościól. Coraz rzadziej słychać głosy o nadciągającej epoce fundamentalizmu katolickiego, że zbliżają się czasy totalnej klerykalizacji życia publicznego, że grozi nam widmo państwa wyznaniowego. Wbrew protestom hierarchii kościelnej i wielu środowisk katolickich do życia publicznego i do ustawodawstwa są wprowadzane rozwiązania całkowicie sprzeczne z doktryną Kościoła katolickiego (np. tzw. ustawa antyprzemocowa, nowe środki antykoncepcyjne „po”, dopuszczalność zapłodnienia pozaustrojowego in vitro).

\section{Uwagi końcowe}

Dla wielu Polaków nauczanie Kościoła katolickiego na temat moralności małżeńsko-rodzinnej, a zwłaszcza moralności seksualnej, to zwykły system retoryki, niebrany na poważnie. Sfera seksu rządzi się odmienną logiką i zasadami niż ta, które sugeruje religia chrześcijańska, a zwłaszcza Kościół katolicki. Seks jest oceniany według satysfakcji lub jej braku, a nie według reguł moralności katolickiej. Znaczna część młodzieży polskiej nie podtrzymuje stanowiska Kościoła w sprawie nierozerwalności małżeństwa. Obserwuje ona, że niemała

\footnotetext{
49 J. Kozielecki, Koniec wieku nieodpowiedzialności, Warszawa 1995 s. 179.

50 Ze wszystkiego można wykuć patkę. Rozmowa z Leszkiem Kołakowskim, [w:] B. Wildstein, Profile wieku, Warszawa 2000 s. 196.
} 
część zawartych małżeństw kończy się rozwodem. W społeczeństwach o charakterze pluralistycznym, będących społeczeństwami doznań i przyjemności, w których organizacja życia społecznego dokonuje się wokół konsumpcyjnego rynku, kształtują się odmienne niż dawniej więzi między ludźmi. Nabierają one charakteru tymczasowości i krótkotrwałości. Dyssatysfakcja czerpana ze związku małżeńskiego jest - według wielu - wystarczającą przyczyną rozwiązania małżeństwa. Można przypuszczać, że w warunkach narastającej „spirali rozwodów" przyzwolenie społeczne na tego typu zachowania będzie wzrastać. Rozwodu nie traktuje się już jako nieszczęścia, lecz jako osobisty, autonomiczny wybór, który wyzwala jednostkę z niekorzystnych sytuacji życiowych. „Istnieje tendencja, by widzieć małżeństwo jako czystą formę uczuciowej gratyfikacji, którą można ustanawiać w jakikolwiek sposób oraz zmienić zależnie od wrażliwości każdego" ${ }^{51}$.

Przeprowadzone analizy socjologiczne pozwalają na koniec na wypunktowanie kilku uwag syntetycznych:

a) przemiany społeczne i kulturowe w Polsce nie zniszczyły i nie wykorzeniły z ludzkiej świadomości sakralnego wymiaru małżeństwa i rodziny. Ujawnia się on - w jakiejś formie - co najwyżej u połowy katolików zawierających sakramentalny związek małżeński. Rodzina jest w Polsce w dalszym ciągu lokowana na pierwszym miejscu w hierarchii wartości uznawanych za najważniejsze w życiu. Większość społeczeństwa polskiego akceptuje model rodziny złożonej z rodziców i dzieci, opowiada się za małżeństwem usankcjonowanym religijnie. Nie sposób jednak nie skonstatować, że wzrasta aprobata rozwodów, związków kohabitacyjnych, stosowania środków antykoncepcyjnych i w znacznie mniejszym stopniu aprobata aborcji. Istnieją silne prądy polityczne i kulturowe usiłujące zmienić definicję małżeństwa. Dzieci nie traktuje się jako dar, lecz jako zaplanowany wybór (techniki reprodukcyjne), a odmawianie prawa parom homoseksualnym do bycia uznanym za małżeństwo i rodzinę uznaje się za przejaw dyskryminacji ${ }^{52}$.

b) Religia tylko w ograniczonym zakresie wpływa na postawy Polaków, w tym i katolików, wobec małżeństwa i rodziny. Nawet wśród deklarujących się jako głęboko wierzący nie brakuje zwolenników współżycia seksualnego przed zawarciem małżeństwa, akceptujących rozwody i stosowanie środków antykoncepcyjnych, a niekiedy nawet i aborcji. Przynależność wyznaniowa i religijna nie zobowiązuje - w przekonaniu wielu wierzących

$51 \quad$ Franciszek, adhortacja apostolska Evangelii Gaudium 66.

52 A. Kwak, Refleksjenad wspótczesna rodzina-kontrowersje, pytania, wartości, [w:] Wspótczesna rodzina polska. Przemiany, zagrożenia i wyzwania, A. Jabłoński, M. Szyszka, D. Gizicka (red.), Lublin 2014, s. 17-31. 
- do tego, by wszystkie treści czy normy danej religii przyjmować w całości. Istnieje tendencja, by wartości i normy religijno-moralne wybierać selektywnie, według własnego uznania. Ten swoisty eklektyzm czy synkretyzm religijno-moralny $\mathrm{w}$ wielu przypadkach nie pociąga za sobą dysonansu afektywno-poznawczego u wierzących, którzy uznając się za wierzących akceptują konkubinat czy seks przed małżeństwem ${ }^{53}$.

c) Zgodnie z przewidywaniami rozumienie sakramentalnego charakteru małżeństwa sytuuje się na niskim poziomie. Badania socjologiczne dotyczące tej kwestii są nieliczne, ale wskazują one przynajmniej tyle, że zdecydowana mniejszość badanej młodzieży udziela w miarę prawidłowych odpowiedzi na pytanie o sakramentalny charakter małżeństwa katolickiego. Najwięcej badanych wybiera odpowiedź, że sakrament małżeństwa oznacza jego nierozerwalność. Inni wskazują na pewne aspekty sakralności tego związku, które są jakby ubocznym skutkiem sakramentalnego charakteru małżeństwa. Wreszcie od 10\% do 15\% ankietowanych przyznaje, że w ogóle nie wie, co to jest sakrament małżeństwa.

d) Znaczący jest rozdźwięk pomiędzy moralno-religijnym nauczaniem Kościoła katolickiego na temat osób żyjących w związkach małżeńskich nieuregulowanych wobec Kościoła a postawami katolików. Wyniki badań socjologicznych w kwestii dopuszczenia tych osób do Komunii św. byly dość rozbieżne i wahały się od 44,0\% do 81,7\% w poszczególnych środowiskach społecznych. Według sondażu CBOS wskaźnik ten w skali ogólnopolskiej obejmował niemal cztery piąte badanych dorosłych Polaków.

e) W społeczeństwie polskim zmieniają się postawy wobec tych zasad życia rodzinnego, które nakazują, aby było ono oparte na sakramentalnym związku małżeńskim. „Życie rodzinne oparte na sakramentalnym związku kobiety i mężczyzny było modelem obowiązującym w polskim społeczeństwie przez całe wieki i do niedawna jeszcze powszechnie upragnionym. Rodziny bez sakramentalnego związku małżeńskiego nie miały aprobaty rodzinnej ani sąsiedzkiej. [...]. Dzisiaj sprawa ta wygląda już inaczej. Można powiedzieć, że opinia sąsiedzka i rodzinna zaaprobowały rodzinę bez sakramentalnego związku małżeńskiego. Coraz mniej zdziwienia budzi nawet wspólne życie kobiety i mężczyzny z ich dziećmi bez żadnego związku małżeńskiego" ${ }^{54}$.

f) Na ogół w społeczeństwach pluralistycznych, zwanych ponowoczesnymi, spada znaczenie (wartość) ślubu kościelnego. Ponieważ jednak zawarcie

53 K. Kamiński, Wplyw religijności narzeczonych na poglady dotyczace regulacji poczęć $i$ przerywania ciaży, „Rocznik Teologii Katolickiej” 13(2014) nr 2, s. 101-114. 
małżeństwa jest ważnym i przełomowym momentem w życiu jednostki, dąży się na ogół do usankcjonowania go jakimś „rytem przejścia”. Zapotrzebowanie na religijne rytuały przy zawieraniu małżeństwa ujawnia się także - raczej z pobudek społecznych i kulturowych - u osób uznających się za niezdecydowane w sprawach wiary czy nawet niereligijne. Współcześnie decyzja zawarcia związku małżeńskiego, także sakramentalnego, częściej niż dawniej ma znaczenie osobiste, wolne od zewnętrznych nacisków.

Uwarunkowania historyczne i współczesne polskiego katolicyzmu sprawiają, że religijność katolików - w porównaniu z krajami Europy Zachodniej - jest bardziej zewnętrzno-kultowa, patriotyczno-narodowa, kościelna i emocjonalno-przeżyciowa, mniej zaś refleksyjna z podbudową intelektualną, mało konsekwentna w sferze postaw i zachowań moralnych (szczególnie w odniesieniu do małżeństwa i rodziny), w mniejszym stopniu stymuluje do samodzielnego i indywidualnego doświadczenia wiary. Wychowanie do wartości moralnych, a zwłaszcza prorodzinnych, jest ważnym zadaniem Kościoła katolickiego w Polsce, bowiem rodzina jest bardzo trwałym środowiskiem wychowania religijnego i moralnego.

Katolicyzm nie jest serią zakazów i nakazów, sprzeciwiających się szczęściu człowieka, ale jest planem życia, który może fascynować i przynieść zaspokojenie najgłębszych pragnień, z odnalezieniem sensu życia włącznie. Jeżeli Kościół katolicki w Polsce niezbyt dobrze sobie radzi z problemami moralnymi swoich wyznawców, to dzieje się tak m.in. dlatego, że zbyt wiele tych problemów pojawiło się do pewnego stopnia jednocześnie i $z$ wielką intensywnością. Kościół przyszłości będzie mniej akcentował nakazy i zakazy, bardziej będzie pomagał swoim członkom w podejmowaniu właściwych decyzji moralnych. Z socjologicznego punktu widzenia są możliwe trzy rozwiązania istniejących konfliktów i napięć: albo modernizacja doktryny moralnej Kościoła, albo reorientacja postaw moralnych ludzi wierzących, albo dalsze nasilanie się postaw zdystansowanych wobec Kościoła, a nawet przyspieszenie procesów laicyzacyjnych w społeczeństwie.

Kościół katolicki w Polsce powinien w swojej działalności być postrzegany, że nie jest on przede wszystkim „przeciw” człowiekowi, lecz „dla” człowieka, rodziny i całego społeczeństwa. Z socjologicznego punktu widzenia nie może być jednak rozważany niezależnie od zmian społecznych i od kontekstu historycznego ${ }^{55}$. On także powinien dostrzegać całą złożoną rzeczywistość, w której żyją i działają jednostki oraz rodziny. Socjolog nie może oceniać wypowiedzi z zakresu doktryny moralnej Kościoła, może jednak stwierdzić, że Kościół

55 F.X. Kaufmann, Kirche angesichts der Ambivalenzen der Moderne, [w:] „Nicht ausserhalb der Welt”. Theologie und Soziologie, M. Striet (red.), Freiburg im Breisgau 2014, s. 93-119. 
instytucjonalny i wierni w sprawach etyki małżeńskiej i rodzinnej mówią odmiennym głosem i do pewnego stopnia przestały siebie wzajemnie słuchać. Nawet regularne praktyki religijne tylko częściowo sprzyjają przyjmowaniu katolickiej moralności małżeńskiej i rodzinnej. Nie jest wykluczone, że dystans wobec doktryny moralnej Kościoła negatywnie oddziałuje zarówno na poziom praktyk religijnych, jak i na inne wymiary religijności.

Znany socjolog amerykański Peter L. Berger twierdzi, że w życiu społecznym człowiek „tworzy wartości i odkrywa, że ma poczucie winy, gdy je narusza” ${ }^{"}$. Wiele faktów wskazuje na to, że wartości prorodzinne, których katolicy nie tworzą, lecz przejmują w warunkach socjalizacji i wychowania w rodzinach i we wspólnotach kościelnych, nie są do końca podzielane i aprobowane. Część katolików polskich kwestionuje niektóre treści religijno-moralnego nauczania Kościoła, zwłaszcza odnoszące się do wartości i norm moralności małżeńsko-rodzinnej. W jakiej mierze odczuwają oni poczucie winy, to pozostaje socjologiczną tajemnicą.

Słowa kluczowe: sakrament małżeństwa, świadomość zbiorowa, młodzież, społeczno-kulturowe przemiany rodziny.

\section{Bibliografia:}

1. Baniak J., Między buntem i sprzeciwem a potrzeba akceptacji i zrozumienia. Kryzys tożsamości osobowej a świadomość religijna i moralna młodzieży gimnazjalnej. Studium socjologiczne, Kraków 2008.

2. Berger P. L., Święty baldachim. Elementy socjologicznej teorii religii, Kraków 1997.

3. Biernat T., Sobierajski P., Młodzież wobec matżeństwa i rodziny. Raport z badań, Torun 2007.

4. Boguszewski R., Kontrowersje wokót różnych zjawisk dotyczacych życia matżeńskiego i rodzinnego, „Komunikat z badań CBOS” 2008 nr 54.

5. Brożek P., Tradycja religijna w środowisku pluralistycznym. Studium socjologiczne, Lublin 2000.

6. Drąg P., Należy troszczyć się o zuykte malżeństwa, „Wiadomości KAI” 2015 nr 16 s. 6.

7. Dyczewski L., Rodzina, spoteczeństwo, państwo, Lublin 1994.

8. Dyczewski L., Wyobrażenia młodzieży o matżeństwie i rodzinie. Pomiędzy tradycja i nowoczesnościa, Lublin 2009.

9. Guzik A., Marzęcki R., Stach Ł., Pokolenie '89. Aksjologia i aktywność młodych Polaków, Kraków 2015.

10. Hipsz N., Spoleczne oceny alternatyw życia małżeńskiego, „Komunikat z badań CBOS” 2013 nr 32.

11. Kamiński K., Matżeństwo i rodzina w świadomości nupturientów. Studium socjologiczne, Lublin 2015 (mps pracy doktorskiej).

$56 \quad$ P. L. Berger, Święty baldachim. Elementy socjologicznej teorii religii, Kraków 1997, s. 38. 
12. Kamiński K., Wptyw religijności narzeczonych na poglady dotyczace regulacji poczęć i przerywania ciąży, „Rocznik Teologii Katolickiej” 13(2014) nr 2 s. 101-114.

13. Kaufmann F.-X., Kirche angesichts der Ambivalenzen der Moderne, [w:] „Nicht ausserhalb der Welt". Theologie und Soziologie, M. Striet (red.), Freiburg im Breisgau 2014, s. 93-119.

14. Kawińska M., Rodzina i zwiazki niesakramentalne we wspólnocie parafialnej-kierunki przemian, [w:] Socjologia życia parafialnego: wspólnota i instytucja. Archidiecezja Warszawska w badaniach Polskiego Pomiaru Postaw $i$ Wartości. S. H. Zaręba, A. Wysocki(red.), Warszawa 2015.

15. Kompendium Katechizmu Kościoła Katolickiego, Kielce 2005.

16. Kowalczuk K., Sfery sacrum i profanum w życiu społecznym, „Komunikat z badań CBOS” 2015 nr 31.

17. Kozak J., Dzieci postmoderny? Studium socjologiczne nad religijnościa studentów, Sandomierz 2014.

18. Kozak J., Rodzina w kryzysie? Esej socjologiczny z racji 120-lecia istnienia Polskiej Misji Katolickiej w Anglii $i$ Walii nad modelami matżeństwa i rodziny w świadomości nupturientów, Lublin 2015.

19. Kozielecki J., Koniec wieku nieodpowiedzialności, Warszawa 1995.

20. Kryczka P., Rozwód w opinii spotecznej, „Studia Socjologiczne” 1999 nr 1.

21. Kwak A., Refleksje nad wspótczesna rodzina - kontrowersje, pytania, wartości, [w:] Wspótczesna rodzina polska. Przemiany, zagrożenia $i$ wyzwania, A. Jabłoński, M. Szyszka, D. Gizicka (red.), Lublin 2014 s. 17-31.

22. Kwak A., Wspótczesny świat zmian - alternatywy dla matżeństwa. [w:] Kobiety i mężczyźni w „postrodzinnym” świecie, E. Paprzycka, J. Czernecka (red.), Łódź 2014, s. 5-19.

23. Kwestionariusz wywiadu EVS 2008 (Research International Pentor), [w:] Wartości $i$ zmiany. Przemiany postaw Polaków w jednoczacej się Europie, A. Jasińska-Kania (red.), Warszawa 2012.

24. Marczewski M., Sakramentalność matżeństwa w ujęciu Jana Pawła II, [w:] Ku prawdzie we wspólnocie człowieka i Boga. Studia dedykowane Ks. Stanisławowi Kowalczykowi, E. Balawajder, P. Nitecki, A. Jabłoński (red.), Sandomierz 1997 s. 479-484.

25. Mariański J., Oczekiwania maturzystów polskich wobec Kościoła katolickiego, [w:] Rodzina w prawie. Księga pamiatkowa dedykowana ks. prof. dr. hab. Ryszardowi Sztychmilerowi z okazji 65. rocznicy urodzin i 30-lecia pracy naukowej, M. Różański, J. Krzywkowska (red.), Olsztyn 2013 s.

26. Mariański J., Sekularyzacja i ewangelizacja. Wartości prorodzinne w świadomości mtodzieży szkót średnich, Lublin 2003.

27. ORRK: jak pomagać parom niesakramentalnym?, „Wiadomości KAI” 2015 nr 17, s. 10-11.

28. Pławecki S., Rozwiedzeni żyjacy w powtórnych zwiazkach jako problem moralno-duszpasterski, [w:] Nadzieje i zagrożenia wspótczesnej rodziny. Międzynarodowe sympozjum moralno-pastoralne Kraków 1994, W. Kawecki (red.), Warszawa 1995.

29. Polak M., Społeczno-kulturowe uwarunkowania duszpasterstwa narzeczonych, „Тeologia Praktyczna” 2(2001). 
30. Raport o stanie wiary. Z Ks. Kardynatem Josephem Ratzingerem rozmawia Vittorio Messori, Kraków - Warszawa-Struga 1986.

31. Roguska B., Oczekiwane zmiany w nauczaniu Kościoła, „Komunikat z badań CBOS” $2015 \mathrm{nr} 32$.

32. Rychlicki C., Sakramentalny charakter przymierza chrześcijańskiego. Studium teologicznodogamtyczne, Płock 1997.

33. Stepulak M. Z., Postawy młodzieży wobec mitości, małżeństwa i rodziny. Badania empiryczne maturzystów z diecezji siedleckiej, „Teologia Praktyczna” 8(2007).

34. Więckiewicz B., Małżenstwo i rodzina w świadomości mtodzieży akademickiej. Stacjonarni studenci dziennikarstwa UKSW $i$ UW (w druku).

35. Wyniki badania „Aktualne problemy i wydarzenia” (nr 297). Komunikat z badań CBOS (do użytku wewnętrznego). CBOS. Warszawa 2015.

36. Wyniki badania „Aktualne problemy i wydarzenia” (nr 297). Komunikat z badań CBOS (do użytku wewnętrznego). Warszawa 2015.

37. Zdaniewicz W., Model katolickiej religijności, [w:] Postawy spoteczno-religijne Polaków 1991-2012, L. Adamczuk, E. Firlit, W. Zdaniewicz (red.), Warszawa 2013.

38. Zdrowe malżenstwa trzeba umacniać. Rozmowa z księdzem arcybiskupem Stanisławem Gądeckim, metropolita poznańskim, przewodniczacym KEP, „Nasz Dziennik” 2015 nr 101.

39. Ze wszystkiego można wykuć patkę. Rozmowa z Leszkiem Kołakowskim, [w:] B. Wildstein, Profile wieku, Warszawa 2000. 